\title{
Organisasiestrukture van landbou-ontwikkelingsinstellings
}

\author{
J. Kroon \\ Departement Bedryfsekonomie, Potchefstroomse Universiteit vir C.H.O., Potchefstroom 2520, Republiek van Suid-Afrika
}

\author{
H.J.P. Steyn
}

Sentrum vir Institusionele Spesialiste, Ontwikkelingsbank van Suider Afrika, Posbus 1234, Halfweghuis 1685, Republiek van Suid-Afrika

\author{
Ontvang November 1992, aanvaar Maart 1993
}

\begin{abstract}
Organization structures of agricultural development institutlons. Agriculture plays an important role in the economic activities of the developing regions of Southern Africa. The public sector has an important role to play in promoting agricultural development. This role can be fulfilled by government departments. These inititutions are, however, often restricted in this function. As a result of this, all the independent states and self-governing territories in Southern Africa have created independent institutions to undertake agricultural development. In this article, attention is firstly given to a short description of agricultural development institutions and following that the approach in organizational design is given. An analysis of the environment in which agricultural development institutions operate is given to serve as basis for proposing a development strategy for these institutions. Based on this proposed strategy, the functions to be performed by agricultural development institutions are formulated, and an organizational structure for agricultural development institutions, is proposed.
\end{abstract}

Landbou speel 'n belangrike rol in die ontwikkelende gebiede van Suider Afrika. Die openbare sektor het 'n groot verantwoordelikheid ten opsigte van die bevordering van landbou-ontwikkeling. Hierdie rol kan deur staatsdepartemente vervul word. Weens verskeie organisatoriese beperkings van sulke instellings het al die onafhanklike state en selfregerende gebiede in Suider Afrika onafhanklike korporatiewe instellings vir landbou-ontwikkeling geskep. In hierdie artikel word landbou-ontwikkelingsinstellings beskryf. Daarna volg ' $n$ bespreking van in benadering tot organisasie-ontwerp. 'n Ontleding van die omgewing waarin sodanige instellings funksioneer, dien as basis vir die formulering van 'n toepaslike ontwikkelingstrategie. Met die strategie as basis word die funksies van landbou-ontwikkelingsinstellings bepaal, en 'n organisasiestruktuur voorgestel.

\section{Inleiding}

Landbou vervul 'n belangrike rol in die ekonomiese aktiwiteite van die ontwikkelende gebiede in Suider-Afrika. ${ }^{1}$ Die owerheidsektor het 'n belangrike rol in die bevordering van landbou-ontwikkeling te speel. Hierdie rol kan deur gewone staatsdepartemente vervul word. Weens administratiewe beperkings is staatsdepartemente nie altyd in staat om die ontwikkelingstaak doeltreffend uit te voer nie (Wallis, 1986: 67). Daarom is daar in al die onafhanklike state en selfregenende gebiede in Suider-Afrika deur die betrokke owerhede instellings geskep wat landbou-ontwikkeling ten doel het. Die vraag kan gestel word of die landbou-ontwikkelingsinstellings organisatories reg gestruktureer is om hulle ontwikkelingstaak in terme van gesonde ekonomiese beginsels uit te voer. Hierdie aangeleentheid is gedurende 1989/1990 ondersoek deur middel van navorsing waarby al tien ontwikkelingsinstellings wat met landbou-ontwikkeling in die selfregerende gebiede en die TBVC-state gemoeid is, betrek is. ${ }^{2}$

Ten aanvang word die begrippe landbou-ontwikkelingsinstelling, organisasiestruktuur en organisasie-ontwerp kortliks omskryf. Daarna word aandag aan die benadering wat in organisasie-ontwerp gevolg word, gegee. Voorts volg 'n ontleding van die omgewing waarin landbou-ontwikkelingsinstellings optree. Met hierdie omgewingsontleding as agtergrond word 'n strategie vir landbou-ontwikkelingsinstellings geformuleer. Daarna word die funksies van landbou-ontwikkelingsinstellings op grond van hulle strategieë geformuleer. Dit vorm die basis vir die formulering van 'n organisasiestruktuur vir 'n landbou-ontwikkelingsinstelling.

\section{Begripsomskrywing}

\section{Landbou-ontwikkelingsinstellings}

'n Reeks tradisionele ekonomiese funksies van die owerheid, waaronder die voorsiening van openbare goedere en die voorkoming van onregverdige mededinging, kan geïdentifiseer word. Vanweë die privaatsektor se onvermoë om doeltreffend in 'n onderontwikkelde ekonomie te funksioneer, het die owerheid hier 'n bepaalde rol te speel (Kindleberger, 1965: 125). Die neiging bestaan om 'onafhanklike' ontwikkelingsinstellings te skep in ' $n$ poging om bestaande beperkende faktore in staatsdepartmente te oorkom.

Ontwikkelingsinstellings is aan owerheidsbeheer onderworpe en kan daarom nie as onafhanklik beskou word nie. In hierdie sin behoort die ontwikkelingsinstelling as ' $n$ verlengstuk van die staatsdepartement gesien te word (Wallis, 1986: 69). Ontwikkelingsinstellings kan derhalwe as diensinstellings, wat daarop ingestel is om beskikbare hulpbronne so doelmatig moontlik aan te wend in ' $n$ poging om ekonomiese ontwikkeling te bewerkstellig, beskryf word (Anthony et al., 1984: 745). Hierby kan gevoeg word dat so 'n owerheidsinstelling primêre ontwikkeling nastreef deur die aanwending van inteme en eksteme hulpbronne in projekte waar die risikofaktor te hoog en die winspotensiaal te laag vir 'n privaatsektoronderneming is (Weideman, 1977: 9).

Opsommenderwys sou ' $n$ ontwikkelingsinstelling die volgende kenmerke hê:

- dit is 'n owerheidsektorinstelling;

- dit streef primĉre ontwikkeling deur die ekonomiese be-

nutting van beskikbare hulpbronne na; en

- dit is outonoom maar nie onafhanklik nie. 
Uitgaande van hierdie samevatting $k a n$ 'n landbou-ontwikkelingsinstelling gedefinieer word as 'n outonome owerheidsektorinstelling met as sy missie die bevordering van ekonomiese ontwikkeling in dic landbousektor. Dit word bewerkstellig deurdat die landbou-ontwikkelingsinstelling se aktiwiteite daarop gemik is om die privaatsektor se deelname in ekonomiese aktiwiteite in die landbousektor optimaal te bevorder (Verenigde Nasies, 1974: 18). Hierdie definisie vorm deurgaans die uitgangspunt in strategieformulering, die bepaling van funksies en die formulering van 'n organisasiestruktuur.

\section{Organisasiestruktuur}

Organisering is 'n deurlopende skeppende proses wat die aktiwiteite van die onderneming deur die toewysing van pligte, verantwoordelikhede en gesag aan persone of afdelings rec̈l. Dit bepaal die verhouding tussen persone ten einde samewerking te bevorder en te streef na die sistematiese uitvoering van werk, sodat die bereiking van doelstellings en doelwitte op 'n doelmatige wyse verseker kan word (De Bruyn, 1984: 9). Hierdie proses word in 'n struktuur beliggaam wat die somtotaal is van die metodes waarvolgens werk ingedeel en koördinasie tussen al die take bewerkstellig word (Mintzberg, 1979: 2). 'n Organisasiestruktuur verteenwoordig die relatief blywende verdeling van werk (Jackson \& Morgan, 1978: 87).

Die organisasiestruktuur behoort as die beliggaming van die proses van organisering gesien te word en word weergegee deur 'n organisasiekaart of organogram - dit is 'n diagram wat die formele gesagsverhouding reflekteer. Die organisasiekaart dui nie die omvang van bevoegdhede en verantwoordelikhede aan nie (Dale, 1978: 108).

\section{Organisasie-ontwerp}

Organisasie-ontwerp is gemoeid met die wyse waarop die onderneming gestruktureer word. Dit kan alleen plaasvind nadat die strategie, wat onder andere deur omgewingsfaktore, hulpbronne en tegnologic beïnvloed word, bekend is. Aangesien die omgewing deurlopend verander, is organisasie-ontwerp nie 'n eenmalige aktiwiteit nie (De Bruyn, 1984: 61).

'n Belangrike stap in organisasiestruktuurontwerp behoort die skepping van 'n doeltreffende verbintenis tussen omgewing, strategie en struktuur te wees (kyk na Figuur 1) (Stoner, 1982: 359.

Die eksteme omgewingsgeleenthede en -bedreigings, asook die interne omgewing se sterk en swak punte, vorm belangrike riglyne vir die ontwikkeling van die ondernemingstrategie. Die strategie word verder deur die doelstellings van die onderneming en die waardestelsels van die onderneming se bestuur beïnvloed. Uit die onderneming se strategie word die funksies wat deur die onderneming uitgevoer moet word, bepaal. Dit dui voorts aan wie die funksies moet uitvoer en hoe dit uitgevoer moet word. Die strategie beïnvloed die ondernemingstruktuur op die volgende drie wyses:

- die strategie bepaal die ondememingstake wat die basis vorm vir organisasie ontwerp;

- die strategie beinvloed die keuse van tegnologie en mense wat benodig word om die take uit te voer; en
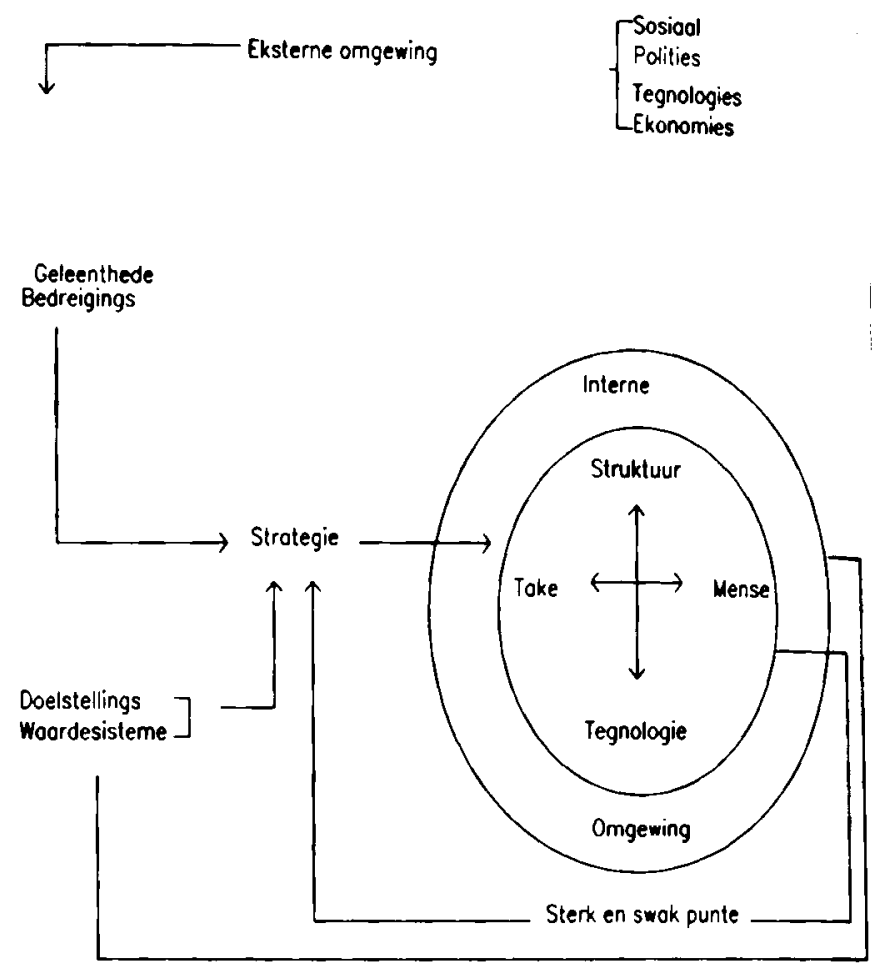

Bron:Stoner

(1982:361)

Figuur 1 Wisselwerking tussen omgewing, strategie en struktuur

- die strategie bepaal die interne omgewing waarbinne die onderneming optree, wat op sy beurt weer die strukturu beinvloed (Stoner, 1982: 360).

Die omgewing verander voortdurend en daarom kan organisasiestruktuur-ontwerp nie as 'n cenmalige aktiwiteit gesien word nie (De Bruyn, 1984: 61) (kyk na Figuur 2). 'n Deeglike ontleding van die omgewing waarin landbou-ontwikkelingsinstellings optree, dien as 'n belangrike bron van inligting vir organisasiestruktuurontwerp.

\section{Navorsingsmetode}

Literatuur in verband met organisering in landbou-ontwikkelingsinstellings is beperk. Daarom is bestaande literatuur ten opsigte van internasionale hulporganisasies, vir sover dit op die Suider-Afrikaanse situasie toepaslik is, bestudeer. Die literatuurstudie is verder aangevul deur die bestudering van literatuur ten opsigte van organisering oor die algemeen en met besondere klem op die matriksorganisasiestelsel. Aan die hand van jaarverslae van landbouontwikkelingsinstellings is die doelstellings en funksies van die landbou-ontwikkelingsinstellings bestudeer. Die inligting is verder aangevul met 'n vraelys wat deur alle landbou-ontwikkelingskorporasies voltooi is en waarin aandag aan die volgende aspekte gegee is:

- huidige organisasiestrukture;

- faktore wat tot die formulering van huidige organisasiestrukture aanleiding gegee het;

- strategiese oorwegings in die formulering van die huidige organisasiestrukture; 


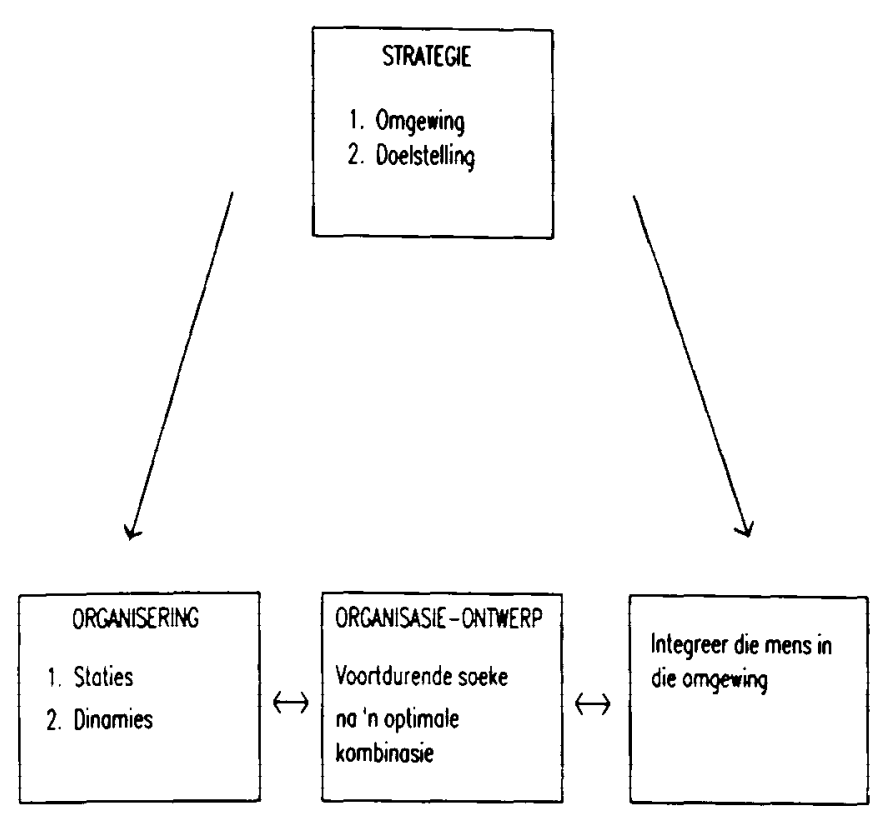

Bron: De Bruyn (1984:63)

Flguur 2 Raamwerk vir organisasiestruktuurontwerp

- voor- en nadele van huidige organisasiestrukture;

- probleme by die toepassing van organisasiestrukture;

- menings or die toepasbaarheid van die matriksorganisasiestruktuur;

- probleme wat met die toepassing van die matriksorganisasiestruktuur voorsien word; en

- die verband tussen omgewing, strategie en struktuur.

'n Totaal van tien landbou-ontwikkelingsinstellings (waarby landbou-ontwikkelingsmaatskappye en 'n algemene ekonomiese ontwikkelingskorporasie met 'n landbouafdeling vir doeleindes van hierdie studie ingesluit is), is in die onafhanklike state en selfregerende gebiede in SuiderAfrika gevestig. Dit was moontlik om al tien die instellings in die studie te betrek.

\section{Omgewing}

Die organisasiestruktuur vorm 'n belangrike skakel tussen die omgewing waarin die onderneming optree en 'n reeks van interne substelsels soos tegnologie, die verhouding tussen mense en take en die bestuurstelsel (Kast \& Rosenzweig, 1985: 240). Daarom is dit belangrik om as vertrekpunt in die proses van organisasiestruktuurformulering, 'n ontleding van landbou-ontwikkelingsinstellings se omgewing te maak.

\section{Eksterne omgewing}

Omgewingsverkenning is noodsaaklik om die sosiale, politiese, ekonomiese en tegnologiese veranderinge in die eksterme omgewing te bepaal, wat die strategiese beplanning van die onderneming kan beïnvloed (Thompson \& Stricland, 1987: 77).

Die meerderheid landbou-ontwikkelingsinstellings het die fisiese omgewing as ' $n$ baie belangrike element van die eksterne omgewing angedui vir sover dit die onderneming in sy ontwikkelingsbenadering beïnvloed (kyk na Tabel 1). Die een helfte het die ekonomiese omgewing as baie belangrik aangedui, terwyl die ander helfte die tegnologiese omgewing as ' $n$ belangrike element aangetoon het.

Die fisiese omgewing het met die landboutoestande en hulpbronbeskikbaarheid te doen wat veral bepalend is ten opsigte van die tipe landboubedrywighede wat gevolg word. Tegnologie het te doen met die toepassing van tegnieke en die toepaslikheid van tegnologie in die fisiese en institusionele omgewings waarin die landbou-ontwikkelingsinstellings optree.

Wat die ekonomiese omgewing betref, was veral beginsels soos privatisering, die afwenteling van besluitneming en die maksimalisering van skakelingseffekte belangrik.

Die produk of diens van 'n landbou-ontwikkelingsinstelling is landbou-ontwikkeling wat deur middel van die beplanning en ontwikkeling van landbouprojekte uitgevoer word. Elke projek word deur ' $n$ eie unieke stel omgewingsfaktore beïnvloed. Alhoewel die diens (produk) stabiel voorkom, het elke diensfunksie sy eie onsekerhede. Omdat elke projek ook uniek is, kan daar wel sprake van 'n snel tempoverandering-in-diens wees. Hierdie verandering hou direk met die aantal projekte wat hanteer word, verband wat die stabiliteit van die produk (diens) wat deur landbouontwikkelingsinstellings gelewer word, beïnvloed. Die feit dat landbou-ontwikkelingsinstellings hoe prioriteit ten opsigte van die fisiese omgewing geniet, dui daarop dat hulle interpretasie van die produk verkeerd mag wees en dat hulle die fisiese produksie van landbouprodukte as die belangrikste uitset beskou. Dit is egter die uitset van die boere wat hulle vestig of ondersteun.

Van mededinging (die mark) in die gewone sin van die woord, is daar in die geval van landbou-ontwikkelingsinstellings nie sprake nie - in al die state van Suider-Afrika is dit die enigste sodanige staatsinstelling. Die omvang van die behoefte na ontwikkeling in die landelike gebiede van die state is egter van so 'n omvang en die hulpbronne so beperk, dat die instellings hulle ontwikkelingstaak op 'n ordelike en goed geprogrameerde basis moet aanpak. So kan 'n bepaalde tempo van ontwikkeling gehandhaaf word en die bestaan van die instellings geregverdig word. Landbouontwikkelingsinstellings moet gevolglik oor die vermoe beskik om vinnig by veranderde ontwikkelingsbehoeftes en -prioriteite aan te pas.

Tabel 1 Eksterne omgewingsfaktore wat die formulering van die organisasiestruktuur beïnvioed

\begin{tabular}{lccccc}
\hline $\begin{array}{l}\text { Ongewings- } \\
\text { faktor }\end{array}$ & $\begin{array}{c}\text { Baie be- } \\
\text { langrik }\end{array}$ & Belangrik & $\begin{array}{l}\text { Minder } \\
\text { belangrik }\end{array}$ & $\begin{array}{l}\text { Onbe- } \\
\text { langrik }\end{array}$ & $\begin{array}{l}\text { Nie aan- } \\
\text { gedui }\end{array}$ \\
\hline Fisieke & 7 & 2 & 1 & - & - \\
Tegnologiese & 2 & 5 & 1 & 1 & 1 \\
Maatskaplike & 1 & 3 & 3 & - & 3 \\
Ekonomiese & 5 & 2 & 2 & - & 1 \\
Politieke & 1 & 2 & 3 & 1 & 3 \\
Institusionele & 3 & 3 & 2 & - & 2 \\
\hline
\end{tabular}




\section{Interne omgewing}

Die interne omgewing bestaan uit vyf substelsels, naamlik:

- Strategie, doelstellings en doelwitte wat hoofsaaklik uit

'n ontleding van die eksterne omgewing afgelei word.

- Die tegniese substelsel: landbou-ontwikkelingsinstellings

tree in die landelike gebiede van onderontwikkelde state

op waar die vermox van die mens (wat sentraal in die ontwikkelingsproses staan) om moderne tegnologie te assimileer, beperk is. Tegnologie is die ontwikkeling en aanwending van kennis vir die bereiking van praktiese doelwitte. Dit sluit nie alleen fisiese hulpmiddels en toerusting in nie, maar ook die prosesse en metodes om probleme op te los en sodoende die verlangde resultate te bereik (Kast \& Rosenzweig, 1985: 208). Dit impliseer dat die landbou-ontwikkelingsinstelling op die mens en sy vermoè om die tegnologie in die ontwikkelingsproses te hanteer, moet konsentreer. Ontwikkelingstegnologie behoort op die bevordering van privaatsektorbetrokkenheid in ekonomiese ontwikkeling en institusionele ontwikkeling gerig te wees (Rondinelli, 1987: 144). Die vermoè van die groep mense betrokke by elke ontwikkelingsprojek om tegnologie te bemeester, het 'n belangrike invloed op die ontwikkelingsbenadering wat deur die landbouontwikkelingsinstelling by so 'n projek gevolg sal moet word.

Alhoewel landbou-ontwikkelingsinstellings in terme van spesiale wetgewing daargestel word, ervaar hulle tog onstabiliteit in die sin dat 'n vae omskrewe of gebrekkige landboubeleid daargestel word (Bembridge, 1986: 25-26). Hierdie aangeleentheid ontvang egter toenemend aandag van die betrokke owerhede, meestal in samewerking met die landbou-ontwikkelingsinstellings, wat die toedrag van sake kan verbeter.

- Die psigologiese substelsel wat die waardes, houdings, verwagtinge en aspirasie van werknemers weerspieël. Landbou-ontwikkelingsinstellings maak gebruik van professionele en tegniese spesialiste wat 'n minder rigiede struktuur vereis (Kast \& Rosenzweig, 1985: 242).

- Die strukturele substelsel wat formele verhoudings, gesagsverhoudings, verantwoordelikhede en werkvloei aandui.

- Die bestuursubstelsel wat die onderneming in sy totaliteit oorspan. Hierdie substelsel skep die verhouding tussen die onderneming en sy eksterne omgewing en bepaal die doelstellings en strategieè van die onderneming. Dit dra by tot die ontwerp van die organisasiestruktuur en die ontwikkeling van beheerprosesse.

Die landbou-ontwikkelingsinstellings het deurgaans doelstellings as die belangrikste element van die interne omgewing aangedui. Hiemaas word besondere klem op die mens in die onderneming geplaas.

\section{Besluitnemingsbehoefte}

Die belangrikste diens wat landbou-ontwikkelingsinstellings lewer, is die beplanning en implementering van ontwikkelingsprojekte. Die hoe mate van produkinnovering wat met elke nuwe projek vereis word, maak bestuursbetrokkenheid op 'n tegniese vlak in 'n vroee stadium reeds noodsaaklik, ten einde omgewingsonsekerheid te verminder. Die matriks. struktuur maak die samevoeging van professionele en teg. niese kundigheid uit 'n verskeidenheid van dissiplines moontlik (Davis \& Lawrence, 1977: 74-75). Sodoende word vroee bestuursbetrokkenheid in produkontwikkeling bewerkstellig (Kingdon, 1973: 22).

Landbou-ontwikkelingsinstellings volg oorwegend divisionele struktuurverdelings terwyl in vier gevalle funksionele struktuurverdelings gevolg word. Kombinasies van funksionele en divisionele struktuurverdelings is by twee landbou-ontwikkelingsinstellings gevind. Drie landbouontwikkelingsinstellings het aangedui dat 'n matriksorganisasiestruktuur in die projekbeplanningsafdelings toegepas word. Die volgende redes is hiervoor aangevoer.

- die verskeidenheid take wat 'n bepaalde aanvangsdatum

het en voor 'n bepaalde spertyd afgehandel moet word, vereis die gekonsentreerde aandag van 'n projekspan vir 'n vasgestelde tydperk;

- die matriksorganisasiestruktuur maak vinnige en doeltreffende hantering van konflik moontlik;

- beleid en prosedures word per projek ontwikkel en toegepas; en

- beplanningsinsette word effektief gekő̈rdineer.

Die belangrikste nadele van die matriksorganisasiestruktuur is meervoudige leiding, komplekse delegasie, groepsvorming, buitensporige oorhoofse koste en komplekse besluitnemingsprosesse (Davis \& Lawrence, 1977: 129. 143). Die hö oorhoofse koste van die matriksorganisasiestruktuur is toe te skryf aan tyd wat deur komitees bestee word, ' $n$ groter behoefte aan kommunikasie en addisionele administrasie. 'n Groter behoefte aan bestuursopleiding dra ook by tot verhoogde oorhoofse koste. Die koste moet egter teen voordele soos beter opgeleide personeel en die ontwikkelingsgeleenthede vir personeel opgeweeg word. 'n Groter getal personeellede kry geleentheid om hulle bestuursvaardighede te ontwikkel (Davis \& Lawrence, 1977: 117-118).

In reaksie op 'n oop vraag het die landbou-ontwikkelingsinstellings die komplekse delegasieprobleem, meervoudige leiding en die moontlike konflik tussen bestuurderdoelwitte en projekdoelwitte as die belangrikste nadele van die matriksorganisasiestruktuur geidentifiseer. Alhoewel koste verbonde aan die toepassing van die organisasiestruktuur deur ses van die landbou-ontwikkelingsinstellings as belangrik aangedui is, het nie een hierdie besondere kenmerk van die matriksorganisasiestruktuur as 'n belangrike nadeel van die struktuur uitgewys nie.

\section{Omgewing as vertrekpunt vir strategieformulering}

Ondememings behoort so gestruktureer te word dat gebeurlikhede in die omgewing op die doeltreffendste wyse moontlik gehanteer kan word. Drie strukturele veranderlikes is moontlik:

- Die vermindering van onsekerheid deur omgewingsontleding, die delegering van gesag en die implementering van standaard- en formele prosedures. So word bedreigings die hoof gebied en vir ordelike administrasie voorsiening gemaak.

- Die toepassing van differensiasietegnieke deur onder andere die aanstelling van ondersteuningspersoneel en 
spesialiste. Hierdeur word staffunksies uitgebrei en spesialiste by gedesentraliseerde besluitneming betrek.

- Ondernemingsintegrasie wat beheerstelsels, koördineringstaakspanne en -komitees, intensiewe vertikale en horisontale kommunikasie en gerekenariseerde bestuursinligtingstelsels insluit (Miller, 1987: 57-59).

Die mate van onsekerheid en onvoorspelbaarheid en die hoeveelheid gebeurlikhede sal belangrike implikasies vir die tipe strukturele veranderlikes en die intensiteit van die toepassing daarvan bepaal. In die hantering van eenvoudige stabiele (voorspelbare) gebeurlikhede kan onsekerheid verminder word deur die aanwending van formele reèls en prosedures, terwyl 'n volledige omgewingsontleding noodsaaklik mag wees om groter en onvoorspelbare gebeurlikhede die hoof te bied.

Landbou-ontwikkelingsinstellings tree in 'n onstabiele eksterne omgewing op wat groter onsekerheid inhou. Dit is daarom belangrik om toepaslike tegnieke aan te wend om onsekerhede te verminder (byvoorbeeld deur deurlopende omgewingsontleding te doen), differensiasietegnieke aan te wend wat daarop gemik is om onder andere interpersoonlike en taakoriëntering van personeel te bevorder en ondernemingsintegrasie te maksimaliseer deur die gebruik van taakspanne, komitees en 'n makıriksorganisasiestruktuur.

\section{Strategle}

Die strategie van ' $n$ onderneming word beskryf as die meesterplan waarvolgens te werk gegaan moet word om die doelstellings van die onderneming te bereik (Wheelen \& Hunger, 1984: 10). Dit impliseer dat die vertrekpunt in enige strategieformuleringsproses ' $n$ evaluering van die onderneming se missie en doelstellings moet insluit.

Daar is reeds aangetoon dat landbou-ontwikkelingsinstellings primêr die verantwoordelikheid het om die landbouontwikkelingsbeleid van hulle regerings uit te voer. Die landbou-ontwikkelingsbeleid behoort daarom in die formulering van die landbou-ontwikkelingsinstelling se missie en doelstellings gereflekteer te word. Dit is veral belangrik dat die doelstellings van die landbou-ontwikkelingsinstelling so geformuleer word dat dit meetbaar in terme van kwaliteit, hoeveelheid, tyd en koste is (Wheelen \& Hunger, 1984: 10). Aspekte soos die aantal boere gevestig of ondersteun gedurende ' $n$ bepaalde periode, die mobilisering van 'n bepaalde hoeveelheid privaatsektorkapitaal vir belegging in die landbousektor van die bepaalde staat gedurende ' $n$ spesifieke periode, en 'n kwantifisering van voorligtings- en opleidingsdienste wat aan boere gedurende 'n bepaalde periode gelewer moet word, behoort die belangrikste sleutelsuksesfaktore te wees.

Die Suider-Afrikaanse streeksontwikkelingsbeleid lê besondere klem op die maksimalisering van privaatsektorbetrokkenheid in die ekonomie. Die implikasie hiervan is dat die openbare sektor hom sover moontlik van die aanwending van natuurlike hulpbronne vir winsdoeleindes moet weerhou (dit wil sê produksie vir eie rekening), en daarna moet streef om toegang tot sodanige hulpbronne vir die totale privaatsektor moontlik te maak. Landbou-ontwikkelingsinstellings se aktiwiteite behoort daarop gemik te wees om dit vir plaaslike gemeenskappe, privaatkontrakteurs, individuele sowel as groepe boere, asook ander privaatsektorinstansies, moontlik te maak om landbou-hulpbronne optimaal in die ekonomiese produksieproses te gebruik (Anon, 1987: 181).

Teen die bostaande agtergrond behoort enige strategie vir 'n landbou-ontwikkelingsinstelling aan die volgende drie kriteria getoets te word:

- Is die verlangde landbou-ontwikkeling moontlik sonder die inmenging van die landbou-ontwikkelingsinstelling?

- Sal die verlangde landbou-ontwikkeling uit die aktiwiteite van die landbou-ontwikkelingsinstelling voortvloei?

- Is die beoogde aktiwiteite van die landbou-ontwikkelingsinstelling tot voordeel van die groepe wat die ondersteuning benodig? (Verenigde Nasies, 1974: 19).

Hierby kan gevoeg word dat die betrokkenheid van die landbou-ontwikkelingsinstelling so gestruktureer moet word dat dit mettertyd onttrek kan word, sonder dat die privaatsektoraktiwiteit onderbreek word.

Met die bogemelde kriteria in gedagte kan die volgende strategie vir 'n landbou-ontwikkelingsinstelling geformuleer word:

Die mobilisering van die privaatsektor tot aktiewe deelname in landbouproduksie en die verlenging van landbouverwante dienste in die ontwikkelende gebiede van SuiderAfrika op so 'n wyse dat die landbousektor tot 'n selfonderhoudende ekonomiese produksietak in die gebiede kan ontwikkel. Dit moet deur die verlening van die volgende dienste geskied:

- Die beplanning van landbou-ontwikkeling deur die uitvoering van beplanningstudies.

- Die skepping van die benodigde landbou-infrastruktuur ten einde die verlening van ondersteuningsdienste aan bestaande en nuutgevestigde boere moontlik te maak.

- Die mobilisering van kommersiële landbou-ondersteuningsdienste soos finansiering, die verskaffing van produksie-insette, meganisasiedienste en die verwerking en bemarking van landbouprodukte.

- Die mobilisering van nie-kommersiële landbou-ondersteuningsdienste soos voorligting, opleiding en toepaslike navorsing.

- Die mobilisering van fondse in die openbare en privaatsektor vir die finansiering van landbou-ontwikkeling.

Dit moet beklemtoon word dat in die formulering van die strategie, die klem op die mobilisering van dienste geplaas word. Dit hou inherent in dat die landbou-ontwikkelingsinstelling se betrokkenheid by ' $n$ projek of program oor die medium tot lang termyn moet uitfaseer en die projek of program selfonderhoudend binne die landelike konteks moet kan funksioneer.

\section{Funksles}

Landbou-ontwikkelingsinstellings het die vestiging van nuwe swart boere, die verlening van ondersteuningsdienste aan bestaande swart boere en die privatisering van eie projekte as hulle belangrikste funksies aangedui (kyk na Tabel 2).

Projekte wat met die bevordering van die privaatsektor in die landbou te doen het, geniet die voorkeuraandag van 
landbou-ontwikkelingsinstellings. Aktiwiteite wat met die ontwikkeling van menslike hulpbronne te doen het (voorligting en opleiding), kan as die tweede belangrikste groep funksies beskou word. Hierdie funksies hou egter direk met boere-ondersteuningsprogramme en die vestiging van nuwe boere verband. In die uitvoering van hulle taak ten opsigte van die ekonomiese ontwikkeling van die land se landboupotensiaal, en binne die raamwerk van 'n beleidstandpunt soos maksimale privaatsektorbetrokkenheid in die landbou, behoort landbou-ontwikkelingsinstellingshulle daarop toe te lê om die funksies uit te voer wat dit vir die privaatsektor moontlik maak om ekonomiese aktiwiteite te beofen. Die funksies van landbou-ontwikkelingsinstellings behoort daarom so gestruktureer te wees dat dit ondersteunend en bevorderend tot die privaatsektor se benutting van ekonomiese hulpbronne in die produksie en verskaffing van goedere en dienste is (OBSA, 1986: 5).

Die volgende algemene funksies van landbou-ontwikkelingsinstellings kan geïdentifiseer word om aan so 'n uitgangspunt beslag te gee:

- Die verskaffing van basiese inligting aan die privaatsektor vir die identifisering, beplanning, beoordeling en implementering van ekonomiese aktiwiteite.

- Die voorsiening van finansieringshulp (hetsy by wyse van lenings of waarborge) waar die privaatsektor deur ekonomiese faktore beperk word om self sodanige fondse te voorsien. In hierdie verband moet landbou-ontwikkelingsinstellings veral poog om privaatsektorfondse te mobiliseer en vir die finansiering van lewensvatbare projekte beskikbaar te stel.

- Die voorsiening van projekgerigte infrastruktuur wat nie deur die privaatsektor voorsien kan word nie.

- Die voorsiening van regeringsfunksies op 'n agentskapsbasis (byvoorbeeld voorligting en opleiding) wat doeltreffender deur die landbou-ontwikkelingsinstelling as deur die staat voorsien kan word.
- Die voorsiening van landbou en ander ekonomiese inligting aan die staat ten einde die deurlopende monitering en hersiening van ontwikkelingsbeleid en strategie moontlik te maak.

- Die aktiewe bevordering van die privaatsektor in landbou-ontwikkeling ('verkoopsbevordering') (kyk na Tabel 2).

Hieruit blyk dit duidelik dat die privaatsektor die vernaamste plek in die benutting van ekonomiese hulpbronne behoort in te neem. Die funksies van landbou-ontwikkelingsinstellings behoort so gestruktureer te word dat hieraan beslag gegee word sonder dat die landbou-ontwikkelingsin. stelling met die privaatsektor meeding (OBSA, 1986: 6-7).

In sy moderne vorm bestaan die landbou-omgewing uit die volgende vier komponente (Mosher, 1979: 5-7):

- Die landbouproduksieproses waarin beskikbare hulpbronne en produksiefaktore gebruik word om landbouprodukte te produseer. Die funksie van landbou-ontwikkelingsinstellings in hierdie komponent behels die beplanning van bestaande en nuwe boerdery-eenhede en die voorsiening van landbou-spesifieke infrastruktuur aan nuwe of bestaande boere.

- Die voorsiening van kommersielle landbou-ondersteuningsdienste soos die voorsiening van produksie-insette, meganisasiedienste, produksiekrediet en die verwerking en bemarking van landbouprodukte. Die voorsiening van hierdie dienste is primêr die privaatsektor se verantwoordelikheid. In 'n ontwikkelende ekonomie is privaatsektorbronne vir sommige of al hierdie dienste dikwels afwesig. In sulke gevalle behoort die landbou-ontwikkelingsinstellings as deel van hulle bevorderingsfunksie sulke dienste te mobiliseer of waar dit afwesig is, tydelik te voorsien. In die laasgenoemde gevalle behoort dit egter so te geskied dat die klimaat kan ontwikkel waarbinne die privaatsektor bereid sal wees om tot die mark toe te tree. Funksies van landbou-ontwikkelingsinstellings in hierdie verband mag selfs stappe ter verwydering van

Tabel 2 Funksies van landbou-ontwikkelingskorporasies

\begin{tabular}{|c|c|c|c|c|c|}
\hline Funksie & $\begin{array}{l}\text { Baie } \\
\text { belangrik }\end{array}$ & Belangrik & $\begin{array}{l}\text { Minder } \\
\text { belangrik }\end{array}$ & $\begin{array}{c}\text { Onbelang- } \\
\text { rik }\end{array}$ & $\begin{array}{l}\text { Nic aan- } \\
\text { gedui }\end{array}$ \\
\hline Boere-ondersteuningsprogramme & 5 & 3 & 1 & - & 1 \\
\hline Boerevestigingsprojekte & 8 & 1 & 一 & - & 1 \\
\hline Privatisering van landbouprojekte & 5 & - & 3 & - & 2 \\
\hline Landbouprojekte vir wins & - & 3 & 1 & 3 & 3 \\
\hline Vestiging van agronyweraars & 2 & 1 & 3 & 1 & 3 \\
\hline Privatisering van agronywerheidsprojekte & 1 & 2 & 2 & 3 & 2 \\
\hline Agronywerheidsprojekte vir wins & $\longrightarrow$ & 一 & - & 4 & 6 \\
\hline Voorligtingsdienste & 2 & 7 & 1 & - & - \\
\hline Opleiding van boere & 3 & 5 & 2 & 一 & 一 \\
\hline Bestuur van köoperasies & 一 & 2 & - & 3 & 5 \\
\hline Opleiding van koöperaticwe personeel & - & - & 3 & 4 & 3 \\
\hline Bestuur van spesiale programme & 一 & - & - & 2 & 8 \\
\hline Kredietverlenging van boere & 1 & 3 & 3 & 1 & 2 \\
\hline Ander & $1 *$ & - & $1 * *$ & 一 & 8 \\
\hline
\end{tabular}


nie-kommersiële risiko's, byvoorbeeld deur die verstrekking van waarborge, insluit (Van Rooyen et al., 1987: 217).

-Die voorsiening van nie-kommersiële landbou-ondersteuningsdienste soos voorligting, opleiding en navorsing. In 'n ontwikkelde ekonomie is privaatsektorinstansies dikwels by die verskaffing van hierdie dienste betrokke. Landbou-ontwikkelingsinstellings het deurgaans aangedui dat hulle hierdie dienste verskaf. Aangesien dit 'n staatsfunksie is (Van Rooyen et al., 1987: 217), behoort landbou-ontwikkelingsinstellings die voorsiening van hierdie dienste te mobiliseer en koobrdineer, of as agent, namens die staat, te verskaf.

- Die ontwikkeling van die landboubeleidsomgewing wat aspekte soos landboubeleid, bemarkingsreellings en -beleid, grondbeheerregulasies en grondbesitstelsels insluit. Die deelname van landbougemeenskappe aan die politieke prosesse, kulturele fakıre en samelewingstrukture vorm ook deel hiervan. Al hierdie elemente hou bepaalde implikasies vir die landboubeleid in. Landbou-ontwikkelingsinstellings is vanweë hulle betrokkenheid in die landelike gemeenskappe in 'n goeie posisie om op 'n deurlopende basis die ontwikkelingsomgewing te monitor en die staat van inligting vir die formulering en hersiening van die landboubeleid te voorsien (OBSA, 1986: 6).

Benewens hierdie funksies wat direk uit 'n ontleding van die landbou-omgewing afgelei kan word, het landbou-ontwikkelingsinstellings die volgende algemene funksies:

- Die mobilisering van fondse in die privaat- en openbare sektore ten einde die ontwikkelingsfunksie te finansier.

- 'n Skakelingsfunksie (verkoopsbevordering) in beide die gevestigde privaatsektor waar beleggings- en ondernemingsgeleenthede bekendgestel moet word, en in die landelike omgewing waar die ontwikkelingsinstelling se dienste bekendgestel moet word.

- Die normale administratiewe, personeelwerwings- en -opleidings- en sekretariële funksies.

Die funksies van landbou-ontwikkelingsinstellings kan as volg in drie kategorieë saamgevat word:

- Operasionele of bedryfsdienste wat die volgende funksies insluit:

* Projekbeplanning en ontwikkeling;

* Beplanning en ontwikkeling van boere-ondersteuningsprogramme;

* Mobilisering van kommersiële landbou-ondersteuningsdienste; en

* Verskaffing of koördinering van nie-kommersiële landbou-ondersteuningsdienste.

- Finansierings- en administratiewe ondersteuningsdienste wat die volgende funksies insluit:

* Mobilisering van ontwikkelingskapitaal;

* Finansiële beheerstelsels;

* Administratiewe ondersteuning;

* Sekretariële dienste; en

* Personeclwerwing en -opleiding.

- Staffunksies wat die volgende insluit:

* Ondersteuning aan die staat met betrekking tot die formulering en hersiening van algemene ekonomiese en landbou-ontwikkelingsbeleid;en
* Bevordering van die landbou-ontwikkelingsinstelling in die onderontwikkelde landelike gebiede en die ontwikkelde privaatsektor.

\section{'n Voorgestelde struktuur}

\section{Vereistes}

Die faktore wat die instelling van 'n matriksorganisasiestruktuur sal regverdig, kan soos volg saamgevat word:

- Wanneer eksterne druk vereis dat intensiewe aandag gelyktydig aan twee of meer verskillende tipes organisatoriese take geskenk moet word (byvoorbeeld funksionele groeperings rondom tegniese vereistes en projekgroeperings om aan unieke kliëntebehoeftes aandag te gee);

- Wanneer die uitvoering van take so kompleks en interafhanklik raak dat bevoegde bestuurders binne die konvensionele organisasiestruktuur nie oor die kapasiteit beskik om inligting voldoende te verwerk nie;

- Wanneer vereis word dat kapasiteitsbesparing en goeie prestasie deur gedeelde en aanpasbare benutting van skaars menslike hulpbronne behaal moet word (Wolf, 1982: 10); en

- Die matriksorganisasiestruktuur is veral geskik waar veelvoudige interafhanklike dissiplines saamgevoeg moet word in die ontwikkeling van nuwe aktiwiteite (Mintzberg, 1979: 173).

Die onstabiele omgewing waarin landbou-ontwikkelingsinstellings optree, verhoog omgewingsonsekerheid. Die organisasiestruktuur behoort daarom vroeè besluitneming, dit wil sê op 'n tegniese vlak, moontlik te maak.

Landbou-ontwikkelingsinstellings se aktiwiteite vereis samewerking tussen verskillende dissiplines. Die organisasiestruktuur behoort 'n samewerkingsmeganisme te voorsien.

Landbou-ontwikkelingsinstellings het primêr 'n bevorderingsfunksie. Die implikasie hiervan is dat die instellings nie permanent by projekte betrokke behoort te raak nie. Die organisasiestruktuur moet daarom mobiliteit ussen projekte verseker. Die uniekheid van die projek stel besondere eise ten opsigte van die beskikbaarheid van kundigheid vir korter of langer tydperke. Die organisasiestruktuur moet hiervoor op so ' $n$ wyse voorsien dat werksekuriteit vir personeel verseker kan word. Dit blyk dat die matriksorganisasiestruktuur geskik behoort te wees vir die strukturering van 'n landbouontwikkelinsinstelling se bedryfsaktiwiteite.

Waar die operasionele funksies van landbou-ontwikkelingsinstellings projekgeoriënteerd is, kan die vraag met reg gevra word of 'n projekorganisasiestruktuur nie ewe doelmatig sal wees nie. Die projekorganisasiestruktuur funksioneer deur middel van klein projekspanne waar die projekleier (bestuurder) 'n smal spanwydte van leiding het, en hoofsaaklik 'n skakelings-, onderhandelings- en koördineringsfunksie vervul (Mintzberg, 1979: 435). Projekte van landbou-ontwikkelingsinstellings verteenwoordig elkeen 'n individucle wins- en kostesentrum, waar die projekbestuurder (projekleier) ten volle 'n bestuursfunksie vervul (Steyn, 1990: 75, 77 en 86). Net soos in die geval van die matriksorganisasiestruktuur, is hoë administratiewe koste, veral ten opsigte van kommunikasie, 'n belangrike nadeel van die projekorganisasiestruktuur (Mintzberg, 1979: 463). 
Uit die cogpunt van 'n behoefte van 'n volle bestuursfunksie, blyk dit dat die matriksorganisasiestruktuur meer doelmatig vir landbou-ontwikkelinginstellings is.

Die skakelingsfunksies en die navorsingsfunksies vorm nie deel van die lynfunksies nie, maar vereis besondere aandag van die topbestuur se kant, veral omdat dit die beeld van die landbou-ontwikkelingsinstelling uitdra. Hierdie funksies behoort daarom albei direk onder die beheer van die hoof uitvoerende beampte geplaas te word.

\section{Organisasiestruktuur}

In Figuur 3 word 'n organisasiestruktuur voorgestel wat die beginsels en vereistes soos hierbo gemotiveer, akkommodeer.

Wat die bedryfsfunksies betref word 'n koordineringsmatriks vorgestel omdat die projekleier die insette van die spesialiste op sy projekspan alleen hoef te koördineer. Die aanname word gemaak dat die spesialiste almal in staat is om rasioneel tot die bereiking van die ondememingsdoelstellings by te dra.

'n Leierskapsmatriks word vir die projekontwikkelingsfunksie voorgestel omdat elke projekbestuurder 'n volledige bestuursfunksie ten opsigte van die bepaalde projek vervul (Gunz \& Pearson, 1977: 27).

Die voorsiening van finansierings-, administratiewe en sekretariële dienste kan groouliks onafhanklik van mekaar funksioneer, maar behoort as ondersteuningsdienste tot die bedryfsfunksie te funksioneer. 'n Diens-divisionele struktuur behoort hier toepaslik te wees (kyk na Figuur 3).

\section{Verduidelikende notas vir Figuur 3}

a) Die getal projekleiers sal deur die beskikbaarheid van geskikte personeel, die getal projekte per projekleier en die verlangde tempo van ontwikkeling bepaal word.

b) Spesialisvelde aangetoon verteenwoordig die mees algemene. Dit word egter deur fisieke omgewingsfaktore beînvloed en kan deur die benutling van eksterne konsultante aangevul word.

c) Die aantal projekbestuurders sal afhang van die vereiste tempo van ontwikkeling en die tempo waarteen projekte voltooi kan word. Koördinasie tussen projekleiers en projekbestuurders is noodsaaklik om te verseker dat alle projekte wat beplan word, onmiddellik geïmplementeer kan word.

\section{Implementering}

Die matriksorganisasiestruktuur word dikwels moeilik deur die personeel wat daarby betrokke is, verstaan omdat dit van die beginsel van enkelskakeling afwyk. Die dubbele gesagslyn verhoog die moontlikheid van rolkonflik, wat vereis dat gesagsbakens ussen projekbestuurders en funksionele bestuurders duidelik gehandhaaf moet word (Davis \& Lawrence, 1977: 130; Kerzner, 1979: 55). Dit is verder belangrik dat personeel moet besef dat hulle in spanne saamwerk en spanprestasie groter $\mathrm{klem}$ as individuele prestasie in die matriksorganisasiestruktuurontvang.

Die volgende voorsorgmaatreexls behoort getref te word vir die instelling van so 'n nuwe organisasiestruktuur:

- Geduld en tyd is nodig om die nuwe stelsel en die personeel bymekaar te laat aanpas.
— 'n Aanpasbare houding moet ingeneem word. Dit mag nodig wees om kleinere struktuurverskuiwings te maak.

- 'n Skema van ondernemingsdoelstellings, doelwitte en strategiee wat as raamwerk vir 'n ontwikkelde projekbestuurskultuur kan dien, moet ontwikkel word.

— Omdat dit vir sommige personeellede moeilik mag wees om by die spankultuur van die matriksorganisasiestruk. tuur aan te pas, behoort senior bestuur besondere ondersteuning aan personeel by die infasering van die stelsel te verleen.

- Positiewe en doeltreffende kommunikasie is belangrik.

- Spesiale meganismes behoort vir die hantering van konflik geskep te word.

\section{Samevatting en gevolgtrekkings}

Die klem wat deur die Suider-Afrikaanse streeksontwikkelingsbeleid op die optimalisering van privaatsektorbetrokkenheid in ekonomiese ontwikkeling geplaas word, het 'n hersiening van die strategieè van landbou-ontwikkelingsinstellings genoodsaak. Binne die raamwerk van die ekonomiese ontwikkelingsbeleid wat algemeen deur state in Suider-Afrika toegepas word, behoort landbou-ontwikkelingsinstellings hulle ontwikkelingsdoelstellings uit te voer deur 'n strategie te volg waarin dit vir die privaatsektor moontlik gemaak word om tot die landbousektor toe te tree. Funksies wat uit so 'n strategie sal voortspruit, sluit aspekte soos die uitvoering van beplanningstudies, die voorsiening van landbou-infrastruktuur en die mobilisering van landbouondersteuningsdienste in. Ontwikkelingswerk geskied op 'n projekbasis en landbou-ontwikkelingsinstellings behoort so gestruktureer te word dat projekte ten volle na die privaatsektor oorgedra kan word wanneer hulle voldoende ontwikkel is. Weens die beperktheid van voldoende kundigheid, is dit belangrik dat organisasiestrukture die optimale benutting van personeel moet moontlik maak.

Die omgewing waarin landbou-ontwikkelingsinstellings optree, vereis dat besondere tegnieke aangewend behoort te word om onsekerheid te verminder. Een van die tegnieke is die toepassing van 'n matriksorganisasiestruktuur, wat nie alleen die benutting van personeel in spanverband verbeter nie, maar ook 'n bree basis skep vir besluitneming op 'n tegniese vlak. Die resultaat hiervan is verbeterde kommunikasie.

\section{Summary}

\section{Agricultural development institutions - a perspective}

Agricultural development institutions were created as independent institutions in the public sector in terms of special legislation to perform the govemment's development function on its behalf. The government, being the sole shareholder in such an institution, can determine the mission and objectives of such an institution.

The mission and objectives should reflect the economic development policy of the relevant govemment. In terms of the regional development policy, as accepted by the Economic Community of Southern African States in 1982, the promotion of private sector involvement in the economy should receive priority attention. In the agricultural sector this can be achieved by establishing individual farmers and supporting existing farmers. 


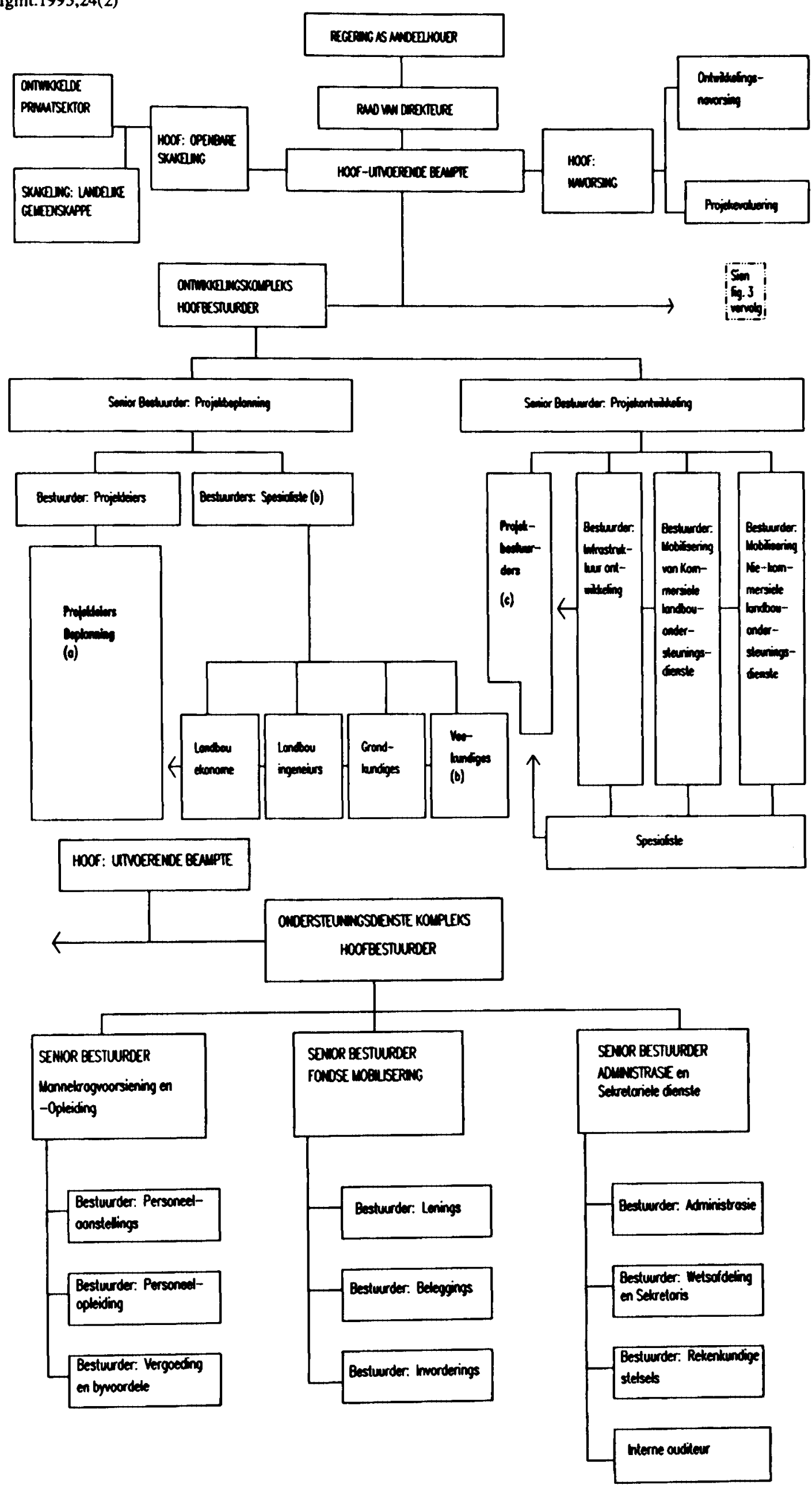

Figuur 3 Voorgestelde organisasiestruktuur 


\section{An approach to organizational design}

Environment and strategy are key variables in the formulation of an organizational structure. Opportunities and threats in the external environment, as well as strengths and weaknesses in the internal environment, are important determinants in the formulation of the strategy through which the institution's objectives can be achieved. The strategy forms the basis for identifying the functions to be performed, the technology to apply and the internal environment in which the institution operates.

\section{Environment}

Agricultural development institutions regard the physical, economic and technological environments as the most important elements of the external environment with regard to the determination of their development approach. Principles such as privatization, devolution of decision-making and maximizing of economic linkages were identified as important elements of the economic environment.

The service rendered by agricultural development institutions, the market in which they operate and the influence of technology and legislation on their activities were analyzed to describe the stability of the external environment. It was concluded that agricultural development institutions operate in an unstable external environment. This instability requires early involvement of management in decision-making at a technical level to reduce the influences of the unstable environment. The matrix organizational structure was identified as an appropriate structure to address the requirements of the unstable environment.

\section{Strategy}

Based on the assumption that agricultural development institutions should promote the principles of private sector involvement in the economy, devolution of decision-making and maximizing of economic linkages, a strategy was proposed which emphasized the promotional role that these institutions should play. Agricultural development institutions should therefore be structured in such a way that as soon as the private sector is established, their responsibilities and involvement should be phased out.

\section{Functions}

Agricultural development institutions regard the establishment of farmers and the rendering of farmer-support programmes as their most important functions. Associated with these are the provision of extension services and training of newly established farmers.

An analysis of the total agricultural sector identified four major components, namely:

- farming which is a private sector function;

- the provision of commercial agricultural support services which is also a private sector function;

- the provision of non-commercial agricultural support services, which is a function of the government; and

- the creation of a stable agricultural policy environment which is also a function of the government.

Agricultural development institutions have a role to play in mobilizing commercial and non-commercial agricultural support services and to support the government in creating the policy environment. These activities will facilitate the involvement of the private sector in the farming operations and in the provision of commercial agricultural suppon services.

\section{A proposed structure}

A structure that will facilitate early management involvement in decision-making and the phasing out of involvement once projects are established, was regarded as necessary for an agricultural development institution. Due to the diversity between operational functions and administra. tive support functions, a matrix approach was proposed for the operational activities, with a co-ordinating matrix for project design and planning, and a leadership matrix for project implementation. Such a structure would facilitate mobility of human resources amongst projects and will ensure employment security for staff. A service orientated divisional structure is proposed for the administrative and financial support services.

In view of the particular features of the matrix structure, such as the dual reporting structure, special attention should be given to the orientation of staff towards adapting to such a structure. It will therefore be important to gradually phase in such a structure over a period of time, to provide the opportunity for staff to adapt to the structure.

\section{Notas}

1. Suider-Afrika sluit vir die doeleindes van hierdie artikel Suid-Afrika, Transkei, Bophuthatswana, Venda, Ciskei en die selfregerende gebiede byvoorbeeld Lebowa, KwaNdebele, ensovoorts in.

2. Die volledige navorsingsresultate is vervat in Steyn (1990: 31-52).

\section{Verwysings}

Anon. 1987. Editorial: An agenda for action in agriculture. Development Southern Africa, Vol. 4, Nr. 2: 178-182, Mei.

Bembridge. T.J. 1986. 'An overview of agricultural and rural development problems in less developed areas of Southern Africa', Development Southern Africa, Vol. 3, Nr. 1: 20-36. Februarie.

Davis, S.M. \& Lawrence, P.R. 1977. Matrix. Massachusetts: Addison Wesley Publishing Company.

De Bruyn, H.E.C. 1984. Verwantskap iussen strategie en organisasiestruktuur van multi-divisionele ondernemings met verwysing na die matriksorganisasie. Proefskrif D.Comm - PU vir CHO. Vereeniging.

Development Bank of Southem Africa. 1986. Memorandwn for discussion with members of directors of the KaNgwane Devel. opment Corporation. Sandion. 17.

Graven, E.H. \& Burger, P.J. 1977. 'The corporations' contribution to agricultural development in the Homelands. In: University of Zululand. The role of development corporation in economic development, paper delivered at a seminar held on 3-5 May 1977. Kempton Park. p.72-78.

Gunz, H.P. \& Pearson, A.W. 1977. 'Matrix organisation in research and development. In Knight, K. (red.). Matrix management. Westmead: Gower. p.22-44.

Kast, F.E. \& Rosenzweig, J.E. 1985. Organisation and management. 4th ed. New York: McGraw-Hill Book Company. 
Kerzner, H. 1979. Project management: a systems approach to planning, scheduling and controlling. New York: Van Nostrand Reinhold Company.

Kingdon, D.R. 1973. Matrix organisation: managing information technologies. Londen: Tavistock.

Miller, D. 1987. 'The structural and environmental correlates of business strategy', Strategic Management Journal, Vol. 8, No. 1: 55-76. January/February.

Mintzberg, H. 1979. The structuring of organisations. Englewood Cliffs, New Jersey: Prentice Hall.

OBSA kyk Development Bank of Southern Africa.

Rondinelli, D.A. 1987. Development administration and US foreign aid policy. Boulder, Colorado: Lynne Rienner Publishers.

Steyn, H.J.P. 1990. 'n Organisasiestruktuur vir ' $n$ landbou ontwikkelingskorporasie. Skripsie M.Comm - PU vir CHO. Potchefstroom.

Stoner, J.A.F. 1982. Management. 2nd ed. Englewood Cliffs, New York: Prentice Hall.

Thompson, A.A. \& Strickland A.J. 1987. Strategic management: concepts and cases. 4th ed. Plano, Texas: Business Publications Inc.
United Nations. 1974. Organisation, management and super. vision of public enterprises in developing countries. New York: United Nations Publication, Sales no. E.74.11.H.4).

Van Rooyen, C.J., Vink, N. \& Christodoulou, N.T. 1987. 'Access to the agricultural market for small farmers in Southem Africa: the farmer support programme', Development Southern Africa, Vol. 4, Nr. 3: 207-223, May.

Verenigde Nasies - kyk na United Nations.

Wallis, J.L. 1986. 'A reappraisal of the role of public enterprises in less developed countries', Development Southern Africa, Vol. 3, Nr. 1: 67-81, February.

Weideman, JJ.S. 1971. 'The role of development corporations'. In: University of Zululand. The role of development corporations in economic development. Paper delivered at a seminar held on 3-5 May 1977 in Kempton Park. p.6-17.

Wheelen, T.L. \& Hunger, J.D. 1984. Strategic management. Menlo Park, Kaliforniè: Addison-Wesley.

Wolff, M.F. 1982. 'Managers at work: welcome to my matrix'. Research Managemen, Vol. 25, Nr. 6: 10-12, November. 